\title{
Hydrothermal synthesis and crystal structure of a mixed-valence pyrochlore-type strontium bismuthate, $\left(\mathrm{Sr}_{0.75} \mathrm{Bi}_{0.25}\right)_{2} \mathrm{Bi}_{2} \mathrm{O}_{6.83}$
}

\author{
Md SAIDUZZAMAN ${ }^{1,2}$, Khandaker Monower HOSSAIN ${ }^{1}$, Nobuhiro KUMADA ${ }^{1, \dagger}$, Sayaka YANAGIDA ${ }^{1}$, \\ Takahiro TAKEI $^{1}$, Yuji HANADA ${ }^{1}$, Masanori NAGAO ${ }^{1}$ and Masaki AZUMA ${ }^{3}$ \\ ${ }^{1}$ Center for Crystal Science and Technology, University of Yamanashi, 7-32 Miyamae-cho, Kofu 400-8511, Japan \\ ${ }^{2}$ Department of Materials Science and Engineering, Khulna University of Engineering and Technology (KUET), \\ Khulna-9203, Bangladesh \\ ${ }^{3}$ Laboratory for Materials and Structures, Tokyo Institute of Technology, 4259 Nagatsuta, Midori-ku, Yokohama 226-8503, Japan
}

A pyrochlore-type strontium bismuthate, $\left(\mathrm{Sr}_{0.75} \mathrm{Bi}_{0.25}\right)_{2} \mathrm{Bi}_{2} \mathrm{O}_{6.83}$ was synthesized by a hydrothermal method using $\mathrm{NaBiO}_{3} \cdot n \mathrm{H}_{2} \mathrm{O}$ as a starting material. The crystal structure was refined using synchrotron powder X-ray diffraction data. The final $R$-factors were $R_{w p}=8.07 \%$ and $R_{p}=5.87 \%$, and the lattice parameter was $a=11.0195$ (2) $\AA$. This compound had a mixed bismuth valence state involving $\mathrm{Bi}^{3+}$ and $\mathrm{Bi}^{5+}$, where $\mathrm{Bi}^{3+}$ partially occupied the A-site $\left(\mathrm{Sr}^{2+}\right)$ as well as the $\mathrm{B}$-site $\left(\mathrm{Bi}^{5+}\right)$ in the pyrochlore-type structure. Moreover, the present compound was found to be a diamagnetic semiconductor with electrical resistivity of $\sim 90 \Omega \mathrm{m}$ at room temperature. (O2020 The Ceramic Society of Japan. All rights reserved.

Key-words : Hydrothermal synthesis, Strontium bismuthate, Pyrochlore

A variety of bismuth oxides have been prepared by hydrothermal reactions using a hydrated sodium bismuth oxide, $\mathrm{NaBiO}_{3} \cdot n \mathrm{H}_{2} \mathrm{O}$. ${ }^{1)-11)}$ Although the crystal structure of $\mathrm{NaBiO}_{3} \cdot n \mathrm{H}_{2} \mathrm{O}$ had been unknown for a long time, we recently clarified it using synchrotron powder X-ray diffraction (SPXRD) data. ${ }^{12)} \mathrm{NaBiO}_{3} \cdot n \mathrm{H}_{2} \mathrm{O}$ had a layered structure related with that of $\mathrm{PbSb}_{2} \mathrm{O}_{6}$, and the removal of water molecules in the interlayer resulted in the transformation to the ilmenite-type structure. ${ }^{6}$ We reported that the reaction with $\mathrm{NaBiO}_{3} \cdot n \mathrm{H}_{2} \mathrm{O}$ in alkaline-earth metal solutions yielded trirutile-type $\mathrm{MgBi}_{2} \mathrm{O}_{6}{ }^{5)} \mathrm{PbSb}_{2} \mathrm{O}_{6}$-type $\mathrm{ABi}_{2} \mathrm{O}_{6}(\mathrm{~A}=\mathrm{Ca}, \mathrm{Sr}, \mathrm{Ba}),{ }^{7), 8), 13}$ ) pyrochlore-type compounds $(\mathrm{Ca}, \mathrm{Sr}, \mathrm{Ba})^{1), 2)}$ and perovskite-type $\mathrm{Ba}_{0.96} \mathrm{Bi}_{0.86}$ $\left.\mathrm{O}_{2.59}(\mathrm{OH})_{0.41}{ }^{4}{ }^{4}\right)$ When a barium chloride solution was used in the room-temperature reaction, the crystallinity of the $\mathrm{PbSb}_{2} \mathrm{O}_{6}$-type $\mathrm{BaBi}_{2} \mathrm{O}_{6}$ product was very low. ${ }^{14)}$ However, a highly crystalline $\mathrm{BaBi}_{2} \mathrm{O}_{6}$ was obtained using a barium hydroxide solution at $120^{\circ} \mathrm{C}$. ${ }^{13)}$ These results suggested that the room-temperature reaction in barium chloride solution was an ion exchange one, ${ }^{14)}$ whereas the reaction in barium hydroxide solution at $120^{\circ} \mathrm{C}$ was a dissolutionrecrystallization process. ${ }^{13)}$ On the other hand, the hydrothermal reaction in strontium nitrate solution at $180^{\circ} \mathrm{C}$ produced pyrochlore-type $\left(\mathrm{Sr}_{0.52} \mathrm{Bi}_{0.4}\right)_{2} \mathrm{Bi}_{2} \mathrm{O}_{6.58}\left(\mathrm{CO}_{3}\right)_{0.14}{ }^{2)}$ however, the hydrothermal reaction in strontium hydroxide solution at $80{ }^{\circ} \mathrm{C}$ yielded pyrochlore-type $\mathrm{Sr}_{2} \mathrm{Bi}_{2} \mathrm{O}_{7}$. ${ }^{1)}$ The different crystal phases were attributed to the different

\footnotetext{
Corresponding author: N. Kumada; E-mail: kumada@ yamanashi.ac.jp
}

reaction temperature and $\mathrm{pH}$ of the solutions, which influence on $\mathrm{Bi}$ valence ratio and/or crystal growth speed of the product. Recently, Wang et al. reported ${ }^{3)}$ the photocatalytic properties of pyrochlore-type $\left(\mathrm{Sr}_{0.60} \mathrm{Bi}_{0.305}\right)_{2}-$ $\mathrm{Bi}_{2} \mathrm{O}_{7}$, prepared by hydrothermal reaction using $\mathrm{NaBiO}_{3}$. $2 \mathrm{H}_{2} \mathrm{O}$ in a $\mathrm{pH}$-adjusted solution of $\mathrm{Sr}\left(\mathrm{NO}_{3}\right)_{2}$ and $\mathrm{NaOH}$ at $160^{\circ} \mathrm{C}$. However, no crystal structure data were included in their study. Recently, we obtained pyrochlore-type $\left(\mathrm{Sr}_{0.75} \mathrm{Bi}_{0.25}\right)_{2} \mathrm{Bi}_{2} \mathrm{O}_{6.83}$ by hydrothermal reaction using $\mathrm{NaBiO}_{3} \cdot n \mathrm{H}_{2} \mathrm{O}$ in a strontium hydroxide solution at $240^{\circ} \mathrm{C}$; the chemical composition of this sample was close to that reported by Wang et al. ${ }^{3)}$ Crystal structure refinement of the $\left(\mathrm{Sr}_{0.75} \mathrm{Bi}_{0.25}\right)_{2} \mathrm{Bi}_{2} \mathrm{O}_{6.83}$ sample was carried out using SPXRD; the differences among three pyrochloretype strontium bismuthates $\left[\mathrm{Sr}_{2} \mathrm{Bi}_{2} \mathrm{O}_{7},\left(\mathrm{Sr}_{0.60} \mathrm{Bi}_{0.305}\right)_{2}-\right.$ $\mathrm{Bi}_{2} \mathrm{O}_{7}$, and $\left.\left(\mathrm{Sr}_{0.75} \mathrm{Bi}_{0.25}\right)_{2} \mathrm{Bi}_{2} \mathrm{O}_{6.83}\right]$ will be discussed in this work.

$\mathrm{NaBiO}_{3} \cdot n \mathrm{H}_{2} \mathrm{O}(2 \mathrm{~g}, 6.5 \mathrm{mmol})$ and $\mathrm{Sr}(\mathrm{OH})_{2} \cdot 8 \mathrm{H}_{2} \mathrm{O}$ with 1:1-1:5 molar ratios were placed into a Teflon-lined autoclave $(70 \mathrm{ml})$. The autoclaves were closed, heated to $240^{\circ} \mathrm{C}$ in an oven, and kept at that temperature for several hours $(1-48 \mathrm{~h})$. The crystal structure of the products were examined by X-ray diffraction (XRD), using a Miniflex600 Rigaku diffractometer with Ni-filtered $\mathrm{CuK}_{\alpha}$ radiation $(\lambda=1.54056 \AA)$. SPXRD measurements were performed on the BL02B2 beamline at SPring-8, Hyogo, Japan. The data were collected with a constant wavelength $(\lambda=$ $0.413356 \AA)$. The crystal structure of the sample was refined using the Rietveld program RIETAN-FP ${ }^{15)}$ and visualized using the VESTA software. ${ }^{16}$ The bismuth 


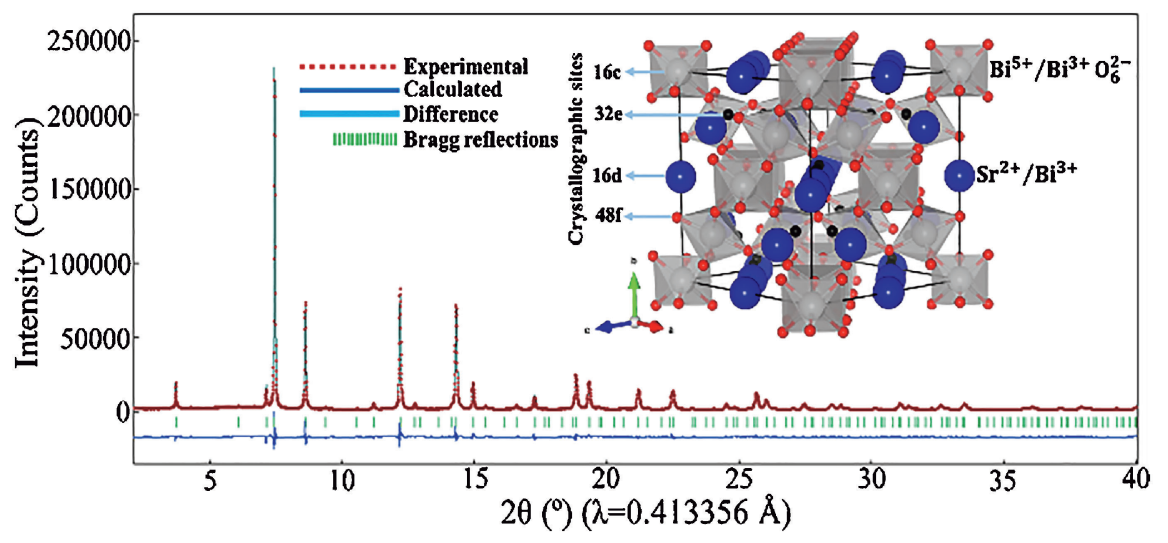

Fig. 1. Rietveld refinement pattern from the SPXRD data for $\left(\mathrm{Sr}_{0.75} \mathrm{Bi}_{0.25}\right)_{2} \mathrm{Bi}_{2} \mathrm{O}_{6.83}$. The insert shows crystal structure with crystallographic sites.

oxidation state was determined by $\mathrm{X}$-ray photoelectron spectroscopy (XPS, JEOL-9200). The temperature dependence of the DC magnetic susceptibility was measured in zero-field cooling (ZFC) and field cooling (FC) conditions with a vibrating sample magnetometer [Physical Property Measurement System (PPMS), Quantum Design]. The room-temperature electrical resistivity of the pressed pellet (at $6 \mathrm{GPa}$ for $30 \mathrm{~min}$ in a cubic anvil-type high-pressure apparatus at room temperature) was measured using a standard four-probe method (PPMS, Quantum Design), with $\mathrm{Ag}$ paste electrodes connected to an $\mathrm{Au}$ wire. Aqueous methyl orange (MO, $10 \mathrm{ppm}$ ) solutions were prepared with ultrapure water, and the catalyst was added at a concentration of $2 \mathrm{~g} / \mathrm{L}$. The solution was stirred and irradiated by visible light from a $300 \mathrm{~W}$ Xe lamp (UXR-300DU, Ushio Inc.), using a $420 \mathrm{~nm}$ sharp cut filter (GG420, Shibuya Optical Co., Ltd.). The time-dependent concentration of MO was evaluated by ultraviolet-visible (UVVis) spectroscopy.

A single-phase pyrochlore-type compound was observed for a Bi:Sr molar ratio of 1:1 at $48 \mathrm{~h}$, whereas an impurity phase was observed in the products with Bi:Sr molar ratios between 1:2 and 1:5 at the same time. The XRD patterns of the products with $\mathrm{Bi}: \mathrm{Sr}=1: 1$ for $1-48 \mathrm{~h}$, revealing that the product for $1 \mathrm{~h}$ was close to a single phase. In the case of pyrochlore-type $\mathrm{Sr}_{2} \mathrm{Bi}_{2} \mathrm{O}_{7}$, a longer time was required ${ }^{1)}$ to obtain the single phase. The slow crystallization of pyrochlore-type $\mathrm{Sr}_{2} \mathrm{Bi}_{2} \mathrm{O}_{7}$ may be due to the lower reaction temperature $\left(80^{\circ} \mathrm{C}\right)$. The single-phase product obtained after $24 \mathrm{~h}$ was used for further characterizations.

Rietveld refinement was carried out on the SPXRD data. The SPXRD pattern of the synthesized $\left(\mathrm{Sr}_{0.75} \mathrm{Bi}_{0.25}\right)_{2}$ $\mathrm{Bi}_{2} \mathrm{O}_{6.83}$ sample could be indexed to a pyrochlore-type structure $[F d \overline{3} m$ (\#227, origin choice 2)] with cubic cell parameter $a=11.0195$ (2) $\AA$, in good agreement with the previous data for pyrochlore-type mixed-valence $\mathrm{Sr}$ bismuthates such as $\left(\mathrm{Sr}_{0.52} \mathrm{Bi}_{0.4}\right)_{2} \quad \mathrm{Bi}_{2} \mathrm{O}_{6.58}\left(\mathrm{CO}_{3}\right)_{0.14}(a=$ $11.01 \AA)$ and $\left(\mathrm{Sr}_{0.60} \mathrm{Bi}_{0.305}\right)_{2} \mathrm{Bi}_{2} \mathrm{O}_{7} \quad(a=11.0161 \AA)$. ${ }^{2), 3)}$ These values are longer than that $[10.94132$ (6) $\AA]$ of the pyrochlore-type $\mathrm{Sr}_{2} \mathrm{Bi}_{2} \mathrm{O}_{7}$ prepared by a low-temperature $\left(80^{\circ} \mathrm{C}\right)$ hydrothermal method. ${ }^{1)}$ In this compound the $\mathrm{B}$
Table 1. Structural parameters for $\left(\mathrm{Sr}_{0.75} \mathrm{Bi}_{0.25}\right)_{2} \mathrm{Bi}_{2} \mathrm{O}_{6.83}$

\begin{tabular}{lllllll}
\hline Atom & Site & $\mathrm{x}$ & $\mathrm{y}$ & $\mathrm{z}$ & $\mathrm{g}$ & $\mathrm{B}_{\text {iso }}\left(\mathrm{A}^{2}\right)$ \\
\hline $\mathrm{Sr}$ & $16 \mathrm{~d}$ & $1 / 2$ & $1 / 2$ & $1 / 2$ & $0.75^{*}$ & $0.60(2)$ \\
$\mathrm{Bi} 1$ & $16 \mathrm{~d}$ & $1 / 2$ & $1 / 2$ & $1 / 2$ & $0.25^{*}$ & $=\mathrm{B}(\mathrm{Sr})$ \\
$\mathrm{Bi} 2$ & $16 \mathrm{c}$ & 0 & 0 & 0 & 1 & $0.67(2)$ \\
$\mathrm{O} 1$ & $48 \mathrm{f}$ & $1 / 8$ & $1 / 8$ & $0.3310(6)$ & 1 & $0.85(2)$ \\
$\mathrm{O} 2$ & $32 \mathrm{e}$ & $0.5635(5)$ & $=\mathrm{x}$ & $=\mathrm{x}$ & $0.83^{*}$ & $1.5^{*}$ \\
\hline
\end{tabular}

*denotes a fixed parameter.

site was occupied only by $\mathrm{Bi}^{5+}$ and the valence distribution of $\mathrm{Bi}$ affected the length of the lattice parameter.

The SPXRD refinement pattern for the $\left(\mathrm{Sr}_{0.75} \mathrm{Bi}_{0.25}\right)_{2}$ $\mathrm{Bi}_{2} \mathrm{O}_{6.83}$ sample is shown in Fig. 1, and the corresponding crystal structure is shown in the inset of the figure. The final $R$-factors were $R_{w p}=8.07 \%$ and $R_{p}=5.87 \%$. The chemical composition of $\left(\mathrm{Sr}_{0.75} \mathrm{Bi}_{0.25}\right)_{2} \mathrm{Bi}_{2} \mathrm{O}_{6.83}$ was determined from the refinement data. The Sr:Bi molar ratio $(0.60: 1)$ obtained from the refined data is close to the energydispersive $\mathrm{X}$-ray spectroscopy (EDX) result $(\mathrm{Sr}: \mathrm{Bi}=$ $0.64: 1)$. The oxygen $(\mathrm{O} 2)$ occupancy $(0.83)$ at the $32 \mathrm{e}$ site was kept fixed for charge balance. The structural parameters are summarized in Table 1.

The mean $\mathrm{Bi}-\mathrm{O}$ distance in the $\mathrm{BiO}_{6}$ octahedral site of $\left(\mathrm{Sr}_{0.75} \mathrm{Bi}_{0.25}\right)_{2} \mathrm{Bi}_{2} \mathrm{O}_{6.83}[2.142(5) \AA]$ is longer than that of $\mathrm{Sr}_{2} \mathrm{Bi}_{2} \mathrm{O}_{7}\left[\mathrm{Bi}-\mathrm{O}=2.09\right.$ (14) $\left.\AA^{1}\right]{ }^{1)}$ The longer $\mathrm{Bi}-\mathrm{O}$ distance of the sample in this study indicates the presence of $\mathrm{Bi}^{3+}$ ions in the $\mathrm{B}$-site, along with $\mathrm{Bi}^{5+}$ species. The combination of XPS and Rietveld refinement results confirmed that approximately $21 \%$ of $\mathrm{Bi}^{3+}$ ions partially occupied the $\mathrm{B}$-site, along with $\mathrm{Bi}^{5+}$. Thus, the valence distribution of bismuth atoms was determined to be $\left(\mathrm{Sr}_{0.75}^{2+} \mathrm{Bi}_{0.25}^{3+}\right)_{2}$ $\left(\mathrm{Bi}_{0.79}^{5+} \mathrm{Bi}_{0.21}^{3+}\right)_{2} \mathrm{O}_{6.83}$, while that of bismuth atoms in $\left(\mathrm{Sr}_{0.60} \mathrm{Bi}_{0.305}\right)_{2} \mathrm{Bi}_{2} \mathrm{O}_{7}$ was $\left(\mathrm{Sr}_{0.60}^{2+} \mathrm{Bi}_{0.305}^{3+}\right)_{2}\left(\mathrm{Bi}_{0.88}^{5+} \mathrm{Bi}_{0.12}^{3+}\right)_{2} \mathrm{O}_{7}{ }^{3)}$ The mean $(\mathrm{Sr}, \mathrm{Bi}-\mathrm{O})$ distance of our synthesized sample was 2.609 (3) $\AA$, which is shorter than the $\mathrm{Sr}-\mathrm{O}$ distance [2.650 (3) $\AA$ ] in $\mathrm{Sr}_{2} \mathrm{Bi}_{2} \mathrm{O}_{7}{ }^{1)}$ ) This was due to the $25 \%$ partial occupancy of the A-site by the $\mathrm{Bi}^{3+}$ species, along with $\mathrm{Sr}^{2+}$ ions.

The presence of $\mathrm{Bi}^{3+}$ was confirmed by the XPS data shown in Fig. 2(a). The two peaks at 162.9 and $164 \mathrm{eV}$ (or 


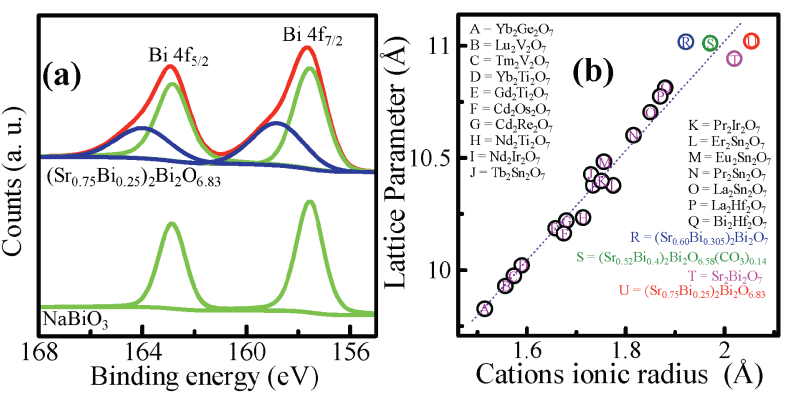

Fig. 2. (a) X-ray photoelectron spectrum of the $\mathrm{Bi} 4 \mathrm{f}_{5 / 2}$ and $4 \mathrm{f}_{7 / 2}$ signals. (b) Cubic unit-cell lattice parameter versus the sum of the ionic radii of the $\mathrm{A}$ and $\mathrm{B}$ cations for pyrochlore-type oxides.

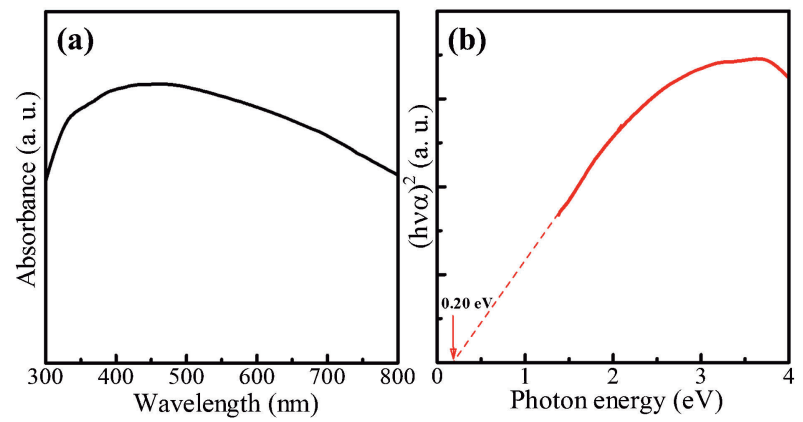

Fig. 3. (a) UV-Vis. absorption spectra of $\left(\mathrm{Sr}_{0.75} \mathrm{Bi}_{0.25}\right)_{2}$ $\mathrm{Bi}_{2} \mathrm{O}_{6.83}$. (b) Tauc plot for the estimation of the band gap for $\left(\mathrm{Sr}_{0.75} \mathrm{Bi}_{0.25}\right)_{2} \mathrm{Bi}_{2} \mathrm{O}_{6.83}$.

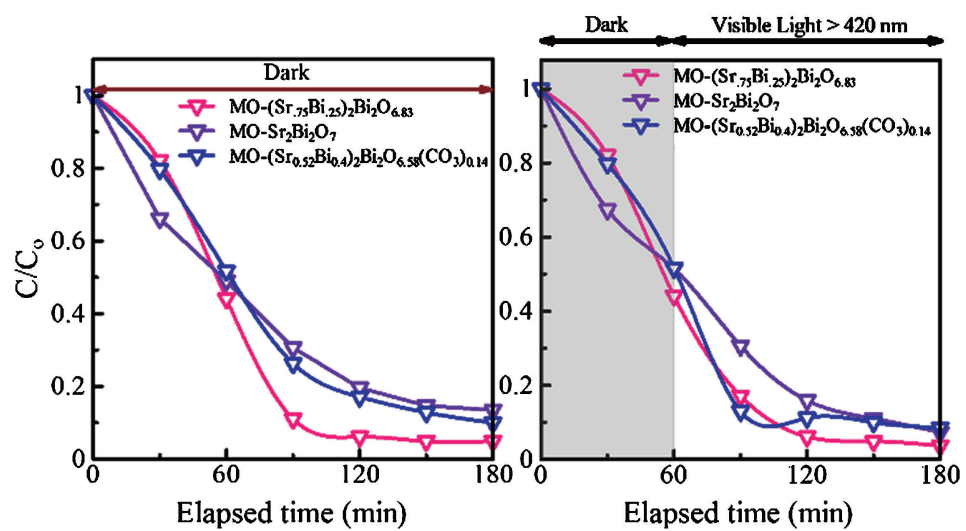

Fig. 4. Adsorption of pyrochlore-type three bismuthates for MO under dark condition (a) and Visible light irradiation (b), respectively.

157.6 and $158.8 \mathrm{eV}$ ) were attributed to $\mathrm{Bi}^{5+}$ and $\mathrm{Bi}^{3+}$, respectively, as indicated in the previous report for $\mathrm{Bi}_{0.75^{-}}$ $\mathrm{Pb}_{0.25} \mathrm{NiO}_{3} .{ }^{17)}$ The average valence of $\mathrm{Bi}$ atoms was found to be 4.26 , with $63 \%$ of $\mathrm{Bi}^{5+}$ and $37 \%$ of $\mathrm{Bi}^{3+}$.

This pyrochlore-type strontium bismuthate follows the linear relationship between the lattice parameter of the cubic unit cell and the sum of the ionic radii of the Aand B-site cations, as shown in various pyrochlore-type oxides [Fig. 2(b)]. Slightly deviation (U) from straight line position could be due to the charge distribution of bismuth.

The temperature dependence of the magnetic susceptibility and electrical resistivity indicates that the present compound is a diamagnetic semiconductor. The electrical resistivity of the pressed sample decreased with increased temperature, and the room-temperature electrical resistivity was found to be $\sim 90 \Omega \mathrm{m}$. This value was higher than that $(0.03 \Omega \mathrm{m})$ of $\mathrm{Sr}_{2} \mathrm{Bi}_{2} \mathrm{O}_{7}{ }^{1)}$ This difference may be due to the higher amount of $\mathrm{Bi}$ present in $\left(\mathrm{Sr}_{0.75} \mathrm{Bi}_{0.25}\right)_{2} \mathrm{Bi}_{2} \mathrm{O}_{6.83}$, because the formation of a covalent bond between $\mathrm{Bi} 6 s$ and $\mathrm{O} 12 p$ orbitals through $s p$ hybridization ${ }^{1)}$ may lead to a high resistivity, while negligible mixing takes place between $\mathrm{O} 22 p$ bands and $\mathrm{Sr}$ sites. ${ }^{1)}$

The strontium bismuthate, $\left(\mathrm{Sr}_{0.75} \mathrm{Bi}_{0.25}\right)_{2} \mathrm{Bi}_{2} \mathrm{O}_{6.83}$ absorption edges lie within the visible region [Fig. 3(a)] and the band gap was found to be $0.20 \mathrm{eV}$ by assuming direct transitions ${ }^{1), 3)}$ as shown in Fig. 3(b). Three types of stron- tium bismuthates show decrease of MO concentration under dark conditions [Fig. 4(a)]. On the other hand, it was reported that $\left(\mathrm{Sr}_{0.60} \mathrm{Bi}_{0.305}\right)_{2} \mathrm{Bi}_{2} \mathrm{O}_{7}$ had photocatalytic activity for $\mathrm{MO}$, but its activity was not checked under dark conditions. ${ }^{3)}$ Under dark and visible light irradiation, the decrease of MO concentration followed the same trend as the experiments in dark conditions for all three $\mathrm{Sr}$ bismuthates, as shown in Fig. 4(b). If these samples have photocatalytic activity, their slopes should change at the switching point from dark to light irradiation. However, there are no changes of slopes as shown in Fig. 4(b). Thus, we can conclude that the decrease of MO concentration under dark experiment could be due to adsorption; a similar result was found for phenol by $\mathrm{Sr}_{2} \mathrm{Bi}_{2} \mathrm{O}_{7}$ in dark experiment. ${ }^{1)}$

In summary, the crystal structure of pyrochlore-type mixed bismuth-valence $\left(\mathrm{Sr}_{0.75} \mathrm{Bi}_{0.25}\right)_{2} \mathrm{Bi}_{2} \mathrm{O}_{6.83}$ was refined by SPXRD. $\mathrm{Bi}^{3+}$ partially occupied the A-site as well as the B-site of the pyrochlore structure along with $\mathrm{Sr}^{2+}$ and $\mathrm{Bi}^{5+}$, respectively. The present compound possessed higher electrical resistivity compared to that of $\mathrm{Sr}_{2} \mathrm{Bi}_{2} \mathrm{O}_{7}$ at room temperature.

Acknowledgments This work was partly supported by JSPS KAKENHI Grant No. 17H03388. The authors would like to thank Dr. C. Moriyoshi for her help with the exper- 
iments at SPring-8. The latter experiments were performed with the approval of the Japan Synchrotron Radiation Research Institute (JASRI, Proposal No. 2019A1190).

\section{References}

1) M. Saiduzzaman, T. Takei, S. Yanagida, N. Kumada, H. Das, H. Kyokane, S. Wakazaki, M. Azuma, C. Moriyoshi and Y. Kuroiwa, Inorg. Chem., 58, 17591763 (2019).

2) N. Kumada, M. Hosoda and N. Kinomura, J. Solid State Chem., 106, 476-484 (1993).

3) X. Wang, L. Liu, H. An, Y. Zhong, D. Wang, C. Tang and C. Hu, Mater. Res. Bull., 118, 110484 (2019).

4) H. Jiang, N. Kumada, Y. Yonesaki, T. Takei and N. Kinomura, J. Ceram. Soc. Jpn., 117, 214-216 (2009).

5) N. Kumada, N. Takahashi, N. Kinomura and A. W. Sleight, Mater. Res. Bull., 32, 1003-1008 (1997).

6) N. Kumada, N. Kinomura and A. W. Sleight, Mater. Res. Bull., 35, 2397-2402 (2000).

7) N. Kumada, N. Xu, A. Miura and T. Takei, J. Ceram. Soc. Jpn., 122, 509-512 (2014).

8) N. Kumada, A. Miura, T. Takei and M. Yashima, J. Asian Ceram. Soc., 2, 150-153 (2014).
9) N. Kumada, A. Miura, T. Takei, S. Nishimoto, Y. Kameshima, M. Miyake, Y. Kuroiwa and C. Moriyoshi, J. Asian Ceram. Soc., 3, 251-254 (2015).

10) M. Saiduzzaman, S. Yanagida, T. Takei and N. Kumada, Mater. Lett., 257, 126688 (2019).

11) M. Saiduzzaman, S. Akutsu, N. Kumada, T Takei, S. Yanagida, H. Yamane and Y. Kusano, Inorg. Chem., 59, 4950-4960 (2020).

12) M. Saiduzzaman, S. Yanagida, T. Takei, N. Kumada, K. Ogawa, C. Moriyoshi, Y. Kuroiwa and S. Kawaguchi, Inorg. Chem., 57, 8903-8908 (2018).

13) M. Saiduzzaman, S. Yanagida, T. Takei, C. Moriyoshi, Y. Kuroiwa and N. Kumada, ChemistrySelect., 2, 4843 4846 (2017).

14) N. Kumada, N. Kinomura and A. W. Sleight, Solid State Ionics, 122, 183-189 (1999).

15) F. Izumi and K. Momma, Solid State Phenom., 130, 1520 (2007)

16) K. Momma and F. Izumi, J. Appl. Crystallogr., 41, 653658 (2008).

17) K. Nakano, K. Oka, T. Watanuki, M. Mizumaki, A. Machida, A. Agui, H. Kim, J. Komiyama, T. Mizokawa, T. Nishikubo, Y. Hattori, S. Ueda, Y. Sakai and M. Azuma, Chem. Mater., 28, 6062-6067 (2016). 